\title{
The Impact of the Exchange Rate Regime on Exports:

\author{
Evidence from Bilateral Exports in the \\ E uropean Monetary System
}

\author{
Kyriacos Aristotelous * \\ Otterbein College \\ Stilianos Fountas \\ National University of I reland, Galan
}

\begin{abstract}
In this paper, we investigated the impact of the creation of the European Monetary System (EMS) on the exports of the four largest EU countries (France, Germany, I taly and UK) to each other. Our findings suggest that the EMS boosted bilateral trade in the cases of Germany's exports to Italy and Italy's exports to the UK and influenced negatively the volume of exports between $\mathrm{F}$ rance and Germany. The EM S had no significant impact on export volumes in the rest of bilateral trade relationships examined. Additionally, we found that exchange rate volatility more often than not had an insignificant effect on the volume of intra-EU exports.
\end{abstract}

*Correspondence Address: Otterbein College Department of Business, Accounting, and Economics One OtterbeinWesterville, Ohio 43081 USA Tel: (614) 823-1611 Fax: (614) 823-1014 Email: Karistotelous@otterbein.edu

We are grateful to the anonymous referees for their helpful comments and suggestions. The usual disclaimer applies.

(C) 2000 - Center for International E conomics, Sejong Institution. All rights reserved. 
a smaller exchange rate variability would increase the quality of information provided by the price mechanism of resource allocation. The fall in risk would reduce the risk premium incorporated in the expected return on investment projects and, hence, the real interest rate, thus, boosting output growth (De Grauwe(1996a)). The result of output growth would be an increase in the demand for exports in foreign countries.

The impact of the ERM on exchange rate uncer tainty represents one of the factors accounting for the change in the volume of intra-EU trade in recent years. An additional factor is the application of tight macroeconomic (monetary and fiscal) policies in most member countries in preparation for their participation in the $\mathrm{EMU}$, as required under the $\mathrm{M}$ aastricht Treaty convergence criteria. These policies, via negative output effects, and in some cases, relative price effects, would be expected to lead to a reduction in the volume of intra-EU trade.

The above discussion indicates that the effect of a change in the exchange rate regime (the creation of the EMS) in the EU on intra-EU trade is, a priori, ambiguous and an empirical investigation is needed to resolve this ambiguity. To this end, we make use of a relatively recent approach to model the determinants of export volume in the four largest EU countries, namely, France, Germany, Italy, and the UK. The econometric methodology utilized applies developments in the econometrics of non-stationary time series in order to estimate long-run and short-run export functions.

Our methodology deviates from the literature on the topic in a number of ways: First, we focus on EU-member countries and analyze explicitly intraEU trade flows. Our motivation derives from the special exchange rate arrangement that applied in these countries since the inception of the EM S. Second, we are especially interested in estimating the impact of the EM S on intra-EU exports in a framework that is general enough to account for several economic determinants of export volumes. To accomplish our objectives, for each country, we estimate a bilateral export function and test for the influence of the exchange rate regime on export volume. We are also interested in the impact of changes in exchange rate uncertainty on export volume, as our findings on this issue will allow us to project the impact of the launch of the single European currency on intra-EU exports.

The paper is organized as follows: Section II presents the theoretical 
The international empirical evidence on the influence of volatility on exports is also mixed. I M F (1984), Cote (1994) and M cKenzie (1999) provide comprehensive reviews of the empirical literature. Early empirical studies disregarded the issue of non-stationarity of macroeconomic time series and used classical regression analysis. These studies, therefore, are subject to the "spurious regression" criticism (Granger and N ewbold, 1974). They include Gotur (1985), Kenen and Rodrik (1986), Koray and Lastrapes (1989), Peree and Steinherr (1989) and Pozo (1992). A number of recent studies test for stationarity of the relevant time series and, in some cases, employ cointegration techniques, e.g., Lastrapes and Koray (1990), Asseery and Peel (1991), Chowdhury (1993), Arize (1995, 1997), Holly (1995) and Fountas and Aristotelous (1999). Kenen and Rodrik (1986), Koray and Lastrapes (1989), Peree and Steinherr (1989), Pozo (1992), Chowdhury (1993), Holly (1995), and Arize (1995, 1997), among others, find evidence of a negative relationship between exchange rate volatility and trade. Asseer y and Peel (1991) show evidence of a positive relationship between exchange rate volatility and trade, while Gotur (1985), Bailey, Tavlas and Ulan (1986), Peree and Steinherr (1989), and Gagnon (1993) were unable to find evidence of any significant effect of exchange rate volatility on trade.

M ost of the above literature uses US dollar exchange rates and, hence, is not directly related with our study that concentrates on ERM exchange rates and intra-EU trade. There are, however, a few exceptions, e.g., De Grauwe (1987), B ini-Smaghi (1991) and Stokman (1995). De Grauwe (1987) and Bini-Smaghi (1991) consider aggregate intra-EM S trade and find evidence that the greater exchange rate stability achieved by the ERM has had a positive effect on intra-ERM trade. Stokman (1995) focuses on the relationship between exchange rate volatility and the volume of intra-EU trade at the sectoral level. He finds that exchange rate volatility is negatively and highly significantly related to intra-EU trade in $90 \%$ of all cases examined. These three studies do not perform stationarity tests and, hence, the common finding of a negative and significant relation between volatility and trade might be spurious. M oreover, these studies do not consider the effect of the exchange rate regime on intra-EU exports, but only the relationship between exports and volatility. However, as mentioned in our introduction, and as further explained below, exchange rate stability obtained by the 
countries (e.g., Ireland and Italy) as relative inflation rates vis-a-vis other member countries were not matched by proportional nominal exchange rate changes, due to the quasi-fixed exchange rate nature of the ERM. These relative price effects on intra-EU exports would also be captured by the inclusion of our ERM dummy variable. De Grauwe (1996b) provides anecdotal evidence that the ERM has been associated with a slowdown in the volume of intra-EU trade.

\section{Econometric Methodology}

In agreement with developments in the econometrics of non-stationary time series, we start by estimating a long-run relationship between exports and its determinants implied by equation (1) using the Johansen multi-variate cointegration approach. In the Johansen framework, all first-difference stationary variables, including exchange rate volatility, are treated as endogenous. The ERM dummy is the only exogenous variable. The treatment of volatility as an endogenous variable is particularly important in the context of the EU where Central Banks have tried systematically to stabilize the nominal exchange rates against the DM and hence against the currencies of the other ERM -member countries.

According to the Granger representation theorem (Engle and Granger(1987)), if the variables in equation (1) are cointegrated, then it can be shown that the error-correction model (ECM) for exports will be of the following form:

$$
\begin{gathered}
\Delta \ln X_{t}={ }_{0}+{ }_{1} R_{t-1}+{ }_{2} D_{t}+\sum_{i=1}^{n}{ }_{i} \Delta \ln X_{t-i}+\sum_{i=1}^{n}{ }_{i} \Delta \ln Y_{t-i}+ \\
\sum_{i=1}^{n}{ }_{i} \Delta \ln P_{t-i}+\sum_{i=1}^{n}{ }_{i} \Delta \ln V_{t-i}+e_{t}
\end{gathered}
$$

where $\Delta$ is the first-difference operator, $\mathrm{R}_{\mathrm{t}-1}$ is the error-correction term

2. France and Germany were members of the ERM during the period 1979.II-1998.III, 2.

. Italy was a member during the periods 1979.II-1992.III and 1996.IV-1998.III and the UK was a member in 1990.IV-1992.III. 
for the sterling/ DM exchange rate which is stationary, are I(1). Then, we proceeded to test for cointegration following the J ohansen maximum likelihood approach among the variables in equation (1). The dummy variable is included in the cointegration procedure as an exogenous variable. We chose the lag length in the VAR using a likelihood ratio test. The results of the trace and maximum eigenvalue tests, also available upon request from the authors, illustrate that there exists a unique cointegrating vector for the majority of bilateral trade relationships studied. For the rest, the tests indicate that there exists more than one cointegrating vector. Following the convention, in this latter group of countries, we have chosen the most significant vector, i.e., the one that corresponds to the largest eigenvalue, in the analysis that follows.

Since the focus of the paper is to examine the impact of the exchange rate regime on export volumes, we do not report the cointegrating vectors. Instead, we focus on the analysis of the short-run dynamics summarized by the estimated ECM S. Using the cointegration vectors normalized on exports, we estimated the ECM s for exports. Tables 1a 1c, 2a 2c, 3a 3c and $4 a \sim 4 c$ report the bilateral short-run export functions for France, Germany, Italy and the UK, respectively. For example, Table la reports the ECM for France's exports to Germany; Table 1b reports the ECM for France's exports to Italy; and Table $1 \mathrm{c}$ reports the ECM of France's exports to the UK. To decide the final forms of the ECM s, we started with the maximum lag suggested by the likelihood ratio test for each variable included in the VAR and eliminated insignificant lags unless this introduced serial correlation in the error term. This allowed us to derive a parsimonious model.

B efore we discuss the results, we need to determine the adequacy of the ECM s. For that reason, we performed a number of tests which are reported in the last column of each table. These tests indicate that the ECM $s$ are adequate for further analysis. The adjusted $\mathrm{R}^{2}$ ranges from a low 0.27 to a high

3. Our main results turned out to be robust to alternative specifications of the order of the moving average.

4. Although we use nominal exchange rates to calculate our volatility measure, Chowdhury (1993), Lastrapes and Koray (1990) and Thursby and Thursby (1987) obtain similar results using nominal and real exchange rates. 
regime, and, hence, can explain why their bilateral intra-EU exports were affected. I taly could, perhaps, be included in this group. However, the lack of an ERM effect for Italy, except for I taly's exports to the UK, according to our results, could be due to the on/ off approach to the ERM, as the country left the system for more than four years in the 1990s. The same explanation applies for the UK that was not part of the system for most of our sample period.

Our finding of a lack of association between the EM S and the volume of intra-EU exports in some countries is also consistent with the literature that has supplied a number of possible explanations for this, a priori, puzzling result (De Grauwe (1996b)). They include, the restrictive fiscal policies followed by the major EM S countries, the supply side problems of many European countries, and the slow-down in the trade integration process within the EU since the 1960s. These factors could have been strong enough to swamp the possible beneficial effects of exchange rate stability resulting from the implementation of EMS.

\section{Summary and Conclusions}

This paper primarily investigated the impact of the creation of the ERM associated with the launch of the EM S in M arch 1979 on the volume of bilateral intra-EU exports using the techniques of multi-variate cointegration and error-correction models. The models were estimated using quarterly data for the four largest EU-member countries, namely, F rance, Germany, Italy, and the UK for the sample period 1973.I-1998.III. The empirical results support two main conclusions:

First, the impact on the EMS on bilateral intra-EU exports has been mixed. The EM S boosted bilateral trade in the cases of Germany's exports to Italy and Italy's exports to the UK. The EMS affected the exports of France to Germany and exports of Germany to France negatively. In the majority of bilateral trade relationships examined, the EM S had no significant impact on export volumes. Second, the short-run effects of exchange rate volatility on export volumes during our sample period have also been mixed. The effect is negative and significant for Italy's exports to France and the UK, and UK's exports to Italy, and positive and significant for 
nomics and Statistics 75; 700-706.

Cote, A. (1994), "Exchange Rate Volatility and Trade," Bank of Canada Working Paper 5.

De Grauwe, P. (1987), "International Trade and Economic Growth in the European M onetary System," European E conomic Review 31; 389-398.

De Grauwe, P. (1988), "Exchange Rate Variability and the Slowdown in Growth of International Trade," I M F Staff Papers 35; 63-84.

De Grauwe, P. (1996a), The E conomics of M onetary Integration (Oxford University Press, Oxford).

De Grauwe, P. (1996b), International M oney (Oxford University Press, Oxford).

Engle, R., and C. W. J . Granger (1987), "Cointegration and Error-Correction: Representation, Estimation, and Testing," E conometrica 55; 251-276.

Feenstra, R.C. and J.D. Kendall (1991), "Exchange Rate Volatility and International Prices," Working Paper No. 3644, National Bureau of Economic Research, Cambridge, $M$ A.

Fountas, S. and K. Aristotelous (1999), "Has the European M onetary System Led to More Exports ? Evidence from Four European Union Countries," E conomics Letters 62; 357-363.

Franke, G. (1991), "Exchange Rate Volatility and International Trading Strategy," Journal of International M oney and Finance 10; 292-307.

Gagnon, J. (1993), "Exchange Rate Variability and the Level of International Trade," Journal of International E conomics 34; 269-287.

Giovannini, A. (1988), "Exchange Rates and Traded Goods Prices," Journal of International Economics 24; 45-68.

Gotur, P. (1985), "E ffects of Exchange Rate Volatility on Trade: Some Further Evidence," I M F Staff Papers 32; 475-512.

Granger, C. W. J. and P. N ewbold(1974), "Spurious Regression in Econometrics," Journal of Econometrics 2; 111-120.

Gros, D. and N. Thygesen (1998), European Monetary Integration, (Longman, Essex).

Holly, S. (1995), "Exchange Rate Uncertainty and Export Performance: Supply and Demand Effects," Scottish Journal of Political Economy 42; 381391.

International M onetary Fund (1984), "Exchange Rate Volatility and World 
520 The Impact of the Exchange Rate Regime on Exports:

$$
X=f\left[Y, P, V_{d}\right]
$$

where $\mathrm{P}=\mathrm{P}_{\mathrm{x}} \mathrm{E} / \mathrm{P}_{\mathrm{x}}{ }^{*}$

and the export supply equation is:

$$
P_{x}=g\left[C, V_{s}\right]
$$

In equation ( $1 \mathrm{~A}), \mathrm{X}$ is the volume of exports, $\mathrm{Y}$ is real foreign income, $\mathrm{P}_{\mathrm{X}}$ is the price of exported goods in terms of domestic currency, $E$ is the foreign currency price of domestic currency, $\mathrm{P}_{\mathrm{x}}{ }^{*}$ is the price of foreign-produced substitutes of exports in foreign currency, and $V_{d}$ is exchange rate risk faced by those demanding exported goods. This risk applies when invoices are denominated in a currency other than that of the demander of exports. $P$ is the relative price which represents a measure of competitiveness. In equation (1B), $C$ is the input cost of domestically-produced exported goods and $V_{S}$ is exchange rate risk faced by domestic producers of exported goods. This risk applies when invoices are denominated in a currency other than that of the supplier. Combining equations (1A) and (1B) above, assuming that the invoice is denominated in either the currency of the supplier or the demander, we obtain a long-run reduced form relationship between export volume and its determinants which in linear form is given by equation (1) in the text, except for the dummy variable.

\section{Table 1a \\ Error-Correction Regression Results : France-Germany \\ (1973:I - 1998:III)}

Dependent Variable: $\ln X$

Note: The figures in parentheses are the absolute t-statistics. * and $* *$ denote significance at the $10 \%$ and $5 \%$ levels, respectively. The F-statistic versions of the LM (4) test statistic for autocorrelation (AR) and the LM (4) test statistic for autoregressive conditional heteroscedasticity $(A R C H)$ are reported followed by marginal significance levels in parentheses.

Table 1b

Error-Correction Regression Results : France-Italy

(1973:I - 1998:III) 


$$
\text { (1973:I - 1998:III) }
$$

Dependent Variable: $2 \ln X$

Note: The figures in parentheses are the absolute t-statistics. * and ** denote significance at the $10 \%$ and $5 \%$ levels, respectively. The F-statistic versions of the LM (4) test statistic for auto-

\begin{tabular}{|c|c|c|c|c|c|c|c|}
\hline lag & $\mathrm{R}$ & Dummy & $2 \ln X$ & $2 \ln Y$ & $2 / \mathrm{nP}$ & $2 \sqrt{ }$ & Summary Statistics \\
\hline 0 & & $\begin{array}{c}0.03 \\
(0.95)\end{array}$ & & & & & \multirow{6}{*}{$\begin{array}{l}\text { Adjusted } R^{2}=0.50 \\
F \text {-statistic }=10.70(0.00) \\
\operatorname{ARF}(4,73)=0.06(0.99) \\
\operatorname{ARCH~} F(4,73)=1.29(0.28)\end{array}$} \\
\hline 1 & $\begin{array}{c}-0.08^{* *} \\
(3.73)\end{array}$ & & $\begin{array}{c}-0.16^{*} \\
(1.71)\end{array}$ & $\begin{array}{l}2.47 * * \\
(3.63)\end{array}$ & $\begin{array}{l}-0.02 \\
(0.06)\end{array}$ & & \\
\hline 2 & & & & $\begin{array}{l}1.23 * \\
(1.71)\end{array}$ & & & \\
\hline 3 & & & $\begin{array}{c}-0.15^{*} \\
(1.97)\end{array}$ & & & & \\
\hline 4 & & & & & & $\begin{array}{l}5.75^{* *} \\
(3.16)\end{array}$ & \\
\hline 5 & & & $\begin{array}{c}-0.34 * * \\
(3.89)\end{array}$ & $\begin{array}{l}1.40^{* *} \\
(2.08)\end{array}$ & & & \\
\hline
\end{tabular}

correlation (AR) and the LM (4) test statistic for autoregressive conditional heteroscedasticity $(A R C H)$ are reported followed by marginal significance levels in parentheses.

Table $2 b$

\section{Error-Correction Regression Results: Germany-Italy}

$$
\text { (1973:I - 1998:III) }
$$

Dependent Variable: $2 \ln X$

Note: The figures in parentheses are the absolute t-statistics. $*$ and $* *$ denote significance at the $10 \%$ and $5 \%$ levels, respectively. The F-statistic versions of the LM (4) test statistic for autocorrelation (AR) and the LM (4) test statistic for autoregressive conditional heteroscedastici-

\begin{tabular}{|c|c|c|c|c|c|c|c|}
\hline lag & $\mathrm{R}$ & Dummy & $2 \ln X$ & $2 \ln Y$ & $\angle \ln P$ & $Q \mathrm{~V}$ & Summary Statistics \\
\hline 0 & & $\begin{array}{l}0.05^{* *} \\
(3.16)\end{array}$ & & & & & \multirow{5}{*}{$\begin{array}{l}\text { Adjusted } R^{2}=0.55 \\
F \text {-statistic }=13.01(0.00) \\
\operatorname{ARF} F(4,74)=1.78(0.14) \\
\operatorname{ARCH~} F(4,74)=0.26(0.90)\end{array}$} \\
\hline 1 & $\begin{array}{c}-0.13^{* *} \\
(3.32)\end{array}$ & & $\begin{array}{c}-0.16^{*} \\
(1.81)\end{array}$ & & & $\begin{array}{c}3.31 \\
(1.18)\end{array}$ & \\
\hline 2 & & & $\begin{array}{l}-0.13 \\
(1.38)\end{array}$ & $\begin{array}{l}2.92^{* *} \\
(2.57)\end{array}$ & $\begin{array}{r}-0.53 \\
(1.33)\end{array}$ & & \\
\hline 3 & & & $\begin{array}{c}-0.11 \\
(1.40)\end{array}$ & & $\begin{array}{c}-0.52 \\
(1.43)\end{array}$ & & \\
\hline 4 & & & $\begin{array}{l}0.58^{* *} \\
(7.22)\end{array}$ & & & & \\
\hline
\end{tabular}
ty $(\mathrm{ARCH})$ are reported followed by marginal significance levels in parentheses. 


$$
\text { (1973:I - 1998:III) }
$$

Dependent Variable: $\ln \mathrm{X}$

Note: The figures in parentheses are the absolute t-statistics. $*$ and $* *$ denote significance at the $10 \%$ and $5 \%$ levels, respectively. The F-statistic versions of the LM (4) test statistic for auto-

\begin{tabular}{|c|c|c|c|c|c|c|c|}
\hline lag & $\mathrm{R}$ & Dummy & $2 \ln x$ & $\angle \ln \mathrm{Y}$ & $2 \ln P$ & $2 N$ & Summary Statistics \\
\hline 0 & & $\begin{array}{c}0.01 \\
(0.73)\end{array}$ & & & & & \multirow{5}{*}{ 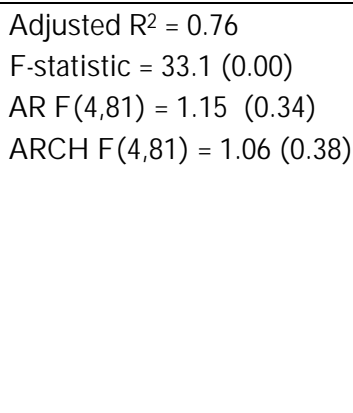 } \\
\hline 1 & $\begin{array}{l}-0.05 \\
(0.95)\end{array}$ & & $\begin{array}{c}-0.63 * * \\
(4.86)\end{array}$ & $\begin{array}{l}4.59 * * \\
(4.23)\end{array}$ & $\begin{array}{c}-0.79 * * \\
(2.33)\end{array}$ & $\begin{array}{c}-3.57 * * \\
(2.15)\end{array}$ & \\
\hline 2 & & & $\begin{array}{c}-0.26 * * \\
(2.10)\end{array}$ & & & & \\
\hline 3 & & & $\begin{array}{c}-0.33^{* *} \\
(2.76)\end{array}$ & & $\begin{array}{c}-0.56^{*} \\
(1.78)\end{array}$ & & \\
\hline 4 & & & $\begin{array}{l}0.29 * * \\
(2.85)\end{array}$ & & & & \\
\hline
\end{tabular}

correlation (AR) and the LM (4) test statistic for autoregressive conditional heteroscedasticity $(A R C H)$ are reported followed by marginal significance levels in parentheses.

\section{Table 3c \\ Error-Correction Regression Results : Italy-UK}

\section{(1973:I - 1998:III)}

\section{Dependent Variable: $2 \ln X$}

Note: The figures in parentheses are the absolute t-statistics. $*$ and $* *$ denote significance at the $10 \%$ and $5 \%$ levels, respectively. The F-statistic versions of the LM (4) test statistic for autocorrelation (AR) and the LM (4) test statistic for autoregressive conditional heteroscedastici-

\begin{tabular}{|c|c|c|c|c|c|c|c|}
\hline lag & $\mathrm{R}$ & Dummy & $y \ln X$ & $\angle \ln Y$ & $y \operatorname{lnP}$ & $2 N$ & Summary Statistics \\
\hline 0 & & $\begin{array}{c}0.01 \\
(0.40)\end{array}$ & & & & & \multirow{5}{*}{$\begin{array}{l}\text { Adjusted } R^{2}=0.49 \\
F \text {-statistic }=12.9(0.00) \\
\operatorname{ARF}(4,80)=0.74(0.57) \\
\operatorname{ARCH~} F(4,80)=0.66(0.62)\end{array}$} \\
\hline 1 & $\begin{array}{c}-0.02 \\
(0.70) \\
\end{array}$ & & $\begin{array}{c}0.37^{* *} \\
(4.08)\end{array}$ & $\begin{array}{c}0.40 \\
(1.17) \\
\end{array}$ & & & \\
\hline 2 & & & & & & & \\
\hline 3 & & & $\begin{array}{l}-0.15 \\
(1.54)\end{array}$ & & $\begin{array}{c}-0.55^{*} \\
(1.75)\end{array}$ & & \\
\hline 4 & & & $\begin{array}{l}0.39 * * \\
(3.96)\end{array}$ & & & $\begin{array}{l}2.94 * \\
\text { (1.85) }\end{array}$ & \\
\hline
\end{tabular}

ty $(\mathrm{ARCH})$ are reported followed by marginal significance levels in parentheses.

\section{Table 4a}

Error-Correction Regression Results : UK-France (1973:I - 1998:III)

Dependent Variable: $2 \ln X$ 
Dependent Variable: $\ln X$

Note: The figures in parentheses are the absolute t-statistics. * and ** denote significance at the $10 \%$ and $5 \%$ levels, respectively. The F-statistic versions of the LM (4) test statistic for autocorrelation (AR) and the LM (4) test statistic for autoregressive conditional heteroscedasticity $(A R C H)$ are reported followed by marginal significance levels in parentheses.

\begin{tabular}{|c|c|c|c|c|c|c|c|}
\hline lag & $R$ & Dummy & $2 \ln X$ & $\dot{s n Y}$ & $2 \operatorname{lnP}$ & $2 \mathrm{~V}$ & Summary Statistics \\
\hline 0 & & $\begin{array}{l}-0.01 \\
(0.51)\end{array}$ & & & & $\begin{array}{c}0.43 \\
(0.60) \\
\end{array}$ & \multirow{6}{*}{ 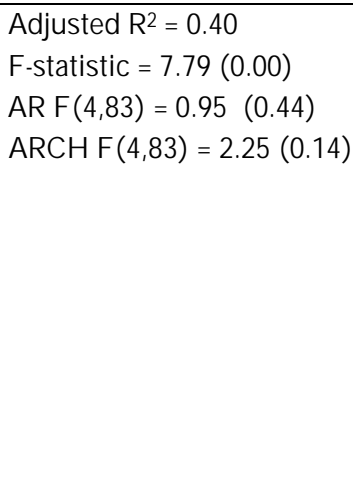 } \\
\hline 1 & $\begin{array}{c}-0.01 \\
(1.04)\end{array}$ & & $\begin{array}{c}-0.47^{* *} \\
(4.80)\end{array}$ & & $\begin{array}{c}-0.29 * \\
(1.66)\end{array}$ & & \\
\hline 2 & & & & & $\begin{array}{l}0.36 * * \\
(2.09)\end{array}$ & & \\
\hline 3 & & & $\begin{array}{l}-0.13 \\
(1.29)\end{array}$ & $\begin{array}{c}0.30^{*} \\
(1.78)\end{array}$ & & & \\
\hline 4 & & & $\begin{array}{l}0.40 * * \\
(3.71)\end{array}$ & & & & \\
\hline 5 & & & $\begin{array}{c}0.16 \\
(1.55) \\
\end{array}$ & & & & \\
\hline
\end{tabular}

\begin{tabular}{|c|c|c|c|c|c|c|c|}
\hline $\operatorname{lag}$ & $\mathrm{R}$ & Dummy & $2 \ln x$ & $\theta \ln Y$ & $2 \ln P$ & $2 \mathrm{~V}$ & Summary Statistics \\
\hline 0 & & $\begin{array}{c}0.02 \\
(0.80) \\
\end{array}$ & & & & & \multirow{5}{*}{$\begin{array}{l}\text { Adjusted R2 }=0.64 \\
F \text {-statistic }=16.29(0.00) \\
\operatorname{AR~} F(4,75)=1.31(0.27) \\
\operatorname{ARCH~} F(4,75)=1.05(0.39)\end{array}$} \\
\hline 1 & $\begin{array}{l}-0.05 \\
(1.34) \\
\end{array}$ & & $\begin{array}{c}-0.35^{* *} \\
(4.11)\end{array}$ & $\begin{array}{l}0.50 * * \\
(2.51)\end{array}$ & $\begin{array}{c}-0.68 * * \\
(2.49)\end{array}$ & & \\
\hline 2 & & & $\begin{array}{c}0.30 * * \\
(3.48) \\
\end{array}$ & & & $\begin{array}{c}4.87 * * \\
(2.05) \\
\end{array}$ & \\
\hline 3 & & & $\begin{array}{c}-0.24 * * \\
(2.84)\end{array}$ & & $\begin{array}{c}-0.69 * * \\
(2.85)\end{array}$ & & \\
\hline 4 & & & $\begin{array}{l}0.62^{* *} \\
(7.60) \\
\end{array}$ & & & & \\
\hline
\end{tabular}

